[15] Inoue-Choi, M., Virk-Baker, M. K., Aschebrook-Kilfoy, B., Cross, A. J., Subar, A. F., Thompson, F. E., Sinha, R., Ward, M. H. (2015). Development and calibration of a dietary nitrate and nitrite database in the NIH-AARP Diet and Health Study. Public Health Nutrition, 19 (11), 1934-1943. doi: 10.1017/ s1368980015003407

[16] Bahadoran, Z., Mirmiran, P., Jeddi, S., Azizi, F., Ghasemi, A., Hadaegh, F. (2016). Nitrate and nitrite content of vegetables, fruits, grains, legumes, dairy products, meats and processed meats. Journal of Food Composition and Analysis, 51, 93-105. doi: 10.1016/j.jfca.2016.06.006

[17] Habermeyer, M., Roth, A., Guth, S., Diel, P., Engel, K.-H., Epe, B., Furst, P., Heinz, V., Humpf, H.-U., Joost, H.-G., Knorr, D., de Kok, T., Kulling, S., Lampen, A., Marko, D., Rechkemmer, G., Rietjens, I., Stadler, R. H., Vieths, S., Vogel, R., Steinberg, P., Eisenbrand, G. (2014). Nitrate and nitrite in the diet: How to assess their benefit and risk for human health. Molecular Nutrition \& Food Research, 59 (1), 106-128. doi: 10.1002/mnfr.201400286

[18] Kukhtyn, M., Vichko, O., Berhilevych, O., Horyuk, Y., Horyuk, V. (2016). Main Microbiological and Biological Properties of Microbial Associations of Lactomyces tibeticus. Research Journal of Pharmaceutical, Biological and Chemical Sciences, 7 (6), 1266-1272.

\title{
DEFINITION OF QUALITY INDICATORS OF DAIRY- PROTEIN CONCENTRATES IN THE STORAGE PROCESS
}

\author{
Victoriya Gnitsevych \\ Department of Technology and the organization of restaurant business \\ Kyiv National University of Trade and Economics \\ 19 Kyoto str., Kyiv, Ukraine, 02156 \\ flamber1965@gmail.com \\ Tatiana Yudina \\ Department of Technology and the organization of restaurant business \\ Kyiv National University of Trade and Economics \\ 19 Kyoto str., Kyiv, Ukraine, 02156 \\ olegdmu@rambler.ru
}

Liudmyla Deinychenko

Department of commodity science, management of safety and quality

Kyiv National University of Trade and Economics

19 Kyoto str., Kyiv, Ukraine, 02156

deliugri@gmail.com

Radion Nykyforov

Department of technology in a restaurant economy that hotel and restaurant business

Donetsk National University of Economics and Trade named after Mykhailo Tugan-Baranovsky 16 Ostrowski str., Krivoy Rog, Ukraine, 50005

nykyforov@donnuet.edu.ua

Iryna Nazarenko

Department of technology in a restaurant economy that hotel and restaurant business

Donetsk National University of Economics and Trade named after Mykhailo Tugan-Baranovsky

16 Ostrowski str., Krivoy Rog, Ukraine, 50005

Nazarenko@donnuet.edu.ua

\footnotetext{
Abstract

The aim of this article is to investigate changes in the structure, color and microbiological parameters of milk-protein concentrates (MPC) made of buttermilk with the use of cranberry or viburnum purees in the process of storage. Necessary results were obtained after analyzing phase transitions, changes in color-parametric and microbiological characteristics of the studied products.
} 
Low-temperature phase transitions and their influence on the structure of MPC were investigated using the method of differential scanning calorimetry. This method was used to obtain information on the change in the temperature function, depending on the change in heat absorption typical for melting, crystallization, or glass transition of components of MPC. The obtained dependences indicated an increase of heat absorption leaps of concentrates in relation to control, which indicates an increase in the amount of bound moisture and, accordingly, a decrease in significant changes in the structure of concentrates in the process of storage. In addition, it was found that rational was the rapid freezing of MPC at a temperature of $-20 \ldots-30{ }^{\circ} \mathrm{C}$.

The CIE XYZ and CIELab methods were used to evaluate the change in the color-parametric characteristics of MPC. According to the data obtained, red or yellow spectral tone dominates for the samples, but with an increase in the storage time, one can see a significant shift in the color of both concentrates towards the yellow color. It is also established that with increasing of storage time there is a gradual darkening of MPC. It was defined, that rational was the shelf life of up to 30 days from the time of studied products making.

It was also determined that with the use of deep freezing of the MPC, the storage time has no significant effect on the development of the microflora.

Keywords: preservation of quality, milk-protein concentrates, differential scanning calorimetry, color-parametric characteristics; microflora; storage. Radion Nykyforov, Iryna Nazarenko

\section{Introduction}

It is known that one of the greatest food deficiencies today is the protein deficiency [1]. Lack of protein in the nutrition causes slowing growth and development of children; deep changes in the functioning of the liver, disorders of the activity of the inner secretion glands, changes in the hormonal background, deterioration in the absorption of nutrients, problems with the heart muscle, deterioration of memory and working capacity of adults.

World experience convincingly suggests that the most effective way of providing the population with the necessary nutrients, namely proteins, is the production of special foods based on concentrates of milk proteins. The valuable protein raw materials for these products are secondary products of the dairy industry, including buttermilk. Such raw material contains almost the entire protein, carbohydrate and mineral complex of whole milk, but is characterized by a low content of fat $[2,3]$. In addition, volumes of production of buttermilk are significant, which makes it expedient for using in the technology of products of special purpose [4].

These data indicate the rationality of the concentration and subsequent use of buttermilk proteins, in particular in the form of milk-protein concentrates (MPC), which are obtained with the use of wild berries of cranberries and viburnum as coagulants [5]. Such concentrates are intended to improve the taste, increase the safety, nutritional and biological value of products on their basis.

Taking into attention the increase of demand for protein concentrates [6, 7], it is expedient to study their quality and properties more observantly, particularly in the fields that have not yet been considered in detail by leading scientists. Therefore, the study of factors that influence the storage of MPC, in particular its structure and organoleptic characteristics, is an urgent task. That is why the aim of this work was to determine the rational method and conditions of freezing of MPC, as well as to analyze their impact on the quality of the studied concentrates.

In order to achieve this aim, the effect of low temperatures and storage time on the structure, color-parametric characteristics and microbiological purity of MPC was studied, which enabled to determine the freezing regimes and the rational terms of storage of these products.

\section{Materials and Methods}

As the object of research were chosen MPC of buttermilk, obtained by the method of thermoacid coagulation. Berry purees were used as coagulants: viburnum puree for making of MPCV and cranberry puree for making of MPCC [5]. Low-fat cottage cheese was chosen as the control sample.

The differential scanning calorimetry (DSC) method was used to study the change in MPC properties with the change in storage temperature. This method is based on the analysis of phase 
transitions, and considers changes in the heat absorption of samples as a function of temperature, which varies with a given speed [8-10].

The study of low-temperature phase transitions of MPC was performed on a differential scanning calorimeter developed by the Institute of Cryobiology and Cryomedicine of the National Academy of Sciences of Ukraine. Scheme of structure and block diagram of calorimeter are shown in Fig. 1, 2. The DSC method was used to obtain information on the temperature of the phase transition, the enthalpy related with the processes of melting, crystallization and glass transition of MPC components.

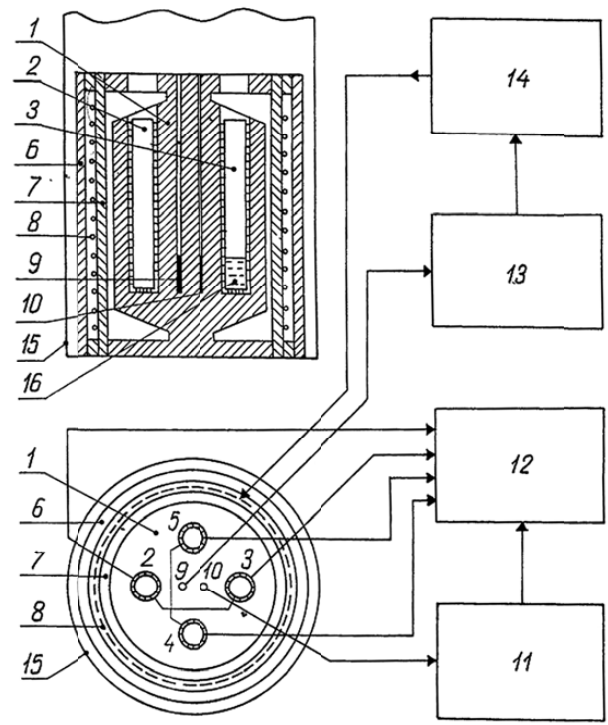

Fig. 1. Scheme of structure of differential scanning calorimeter

The device is based on the traditional design of Kalve calorimeter. In copper calorimetric block 1 there are four cavities, with calorimetric container (2-5) installed in each (Fig. 1). Each of the calorimetric containers is a copper cup surrounded by a battery of thermocouples, which are connected in series. The outputs of the thermocouples of calorimetric containers are connected in couples in a differential schema. The container 2 is connected to the container 3 and the container 4 with the container 5. Thus, in the calorimeter there are two independent channels for simultaneous examination of two samples. During the experiments, a special design of thermocouples with high thermal conductivity was used in order to provide a small thermal inertia of calorimetric containers. This is important for the operation of the calorimeter in the temperature scan mode.

The calorimetric block is surrounded by heat screens 6 and 7, between which the heater 8 is located. In the middle of the calorimetric block there are two openings where the thermometers of the resistance 9 and 10 are installed. The resistance thermometer 9 is used in the system of automatic temperature control of the calorimetric block. It is connected to the software temperature control block 13, which controls the operation of the heater 8 through the control device 14 . The resistance thermometer 10 is designed to measure the temperature of the calorimetric block. It is connected to the temperature measurement block 11. The calorimetric block temperature is recorded by device 12. At the same time, two signals are recorded from each of the pairs of calorimetric containers at the same time. The calorimetric block is placed in a hermetic stainless steel chamber 15, which is located in a Dewar vessel with liquid nitrogen. A chamber with a calorimetric block may either be located above the surface of liquid nitrogen or be immersed in liquid nitrogen.

The investigated sample 16 is placed in a thin-walled glass of stainless steel (wall thickness of $0,1 \mathrm{~mm}$ ), closed tightly with a lid and installed in a calorimetric container. In the other container the same empty cup is installed. Two independent measurement channels allow to record thermograms of two samples at the same time in absolutely identical conditions of temperature scanning. 
This method of study allows to record very small differences in the thermophysical properties of two samples (Fig. 2).

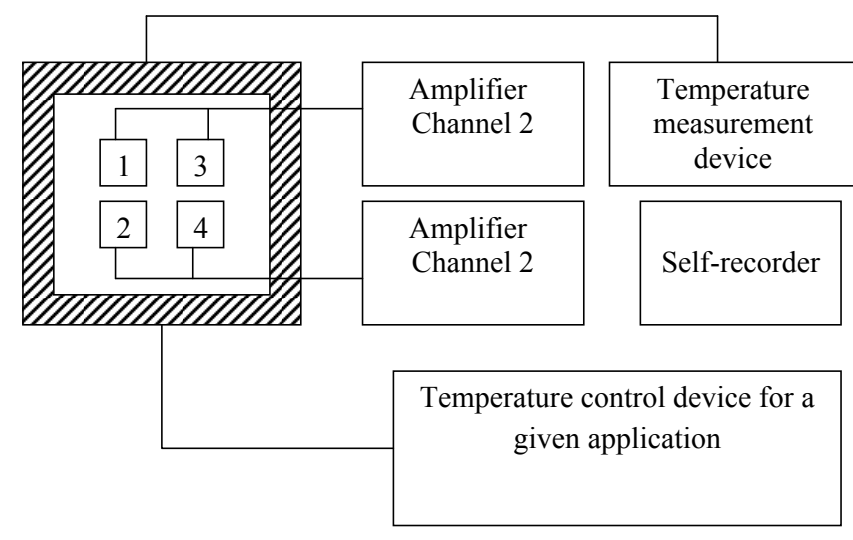

Fig. 2. Block diagram of differential scanning calorimeter

Color evaluation methods of CIE XYZ and CIELab systems were used to evaluate the color properties [11]. The CIEXYZ method is based on measuring of the spectral coefficients of diffuse reflection of samples (Rf, \%) and mathematical processing using the SFScan software. The obtained color coordinates and graphs constructed on the basis of these coordinates allow to determinate the indicators such as the purity of the tone (P, \%), the brightness $(\mathrm{T}, \%)$ and the dominant wavelength $(\lambda)$.

Another method for determining the color characteristics used in the work is the CIELab method based on the Hunter tricolorometric system, and which allows to characterize the color by parameters of brightness (L) and color components (a for green-red components and $b$ for blue-yellow).

After obtaining of the coordinates by the CIE XYZ method, using mathematical processing one can obtain the correlation between the two systems. This allows to get a more complete description of the color-parametric indexes of the studied products.

The diffuse reflection coefficients of the samples were determined on a spectrophotometer SF-2000 (“OKB SPECTRUM”, Russia) with a prefix of diffuse and mirror reflection SFO-2000, which allows spectra measuring in the range $300 \ldots 800 \mathrm{~nm}$ with the spectral cleft $0,05 \ldots 0,25 \mathrm{~mm}$, the range of angle variation between the normal to the surface of the sample and the direction of illumination - from $0^{\circ}$ to $45^{\circ}$, the range of the angle between the normal to the surface of the sample and the reflection direction - from $0^{\circ}$ to $45^{\circ}$.

The calculations for the received spectra were processed in the software SFScan.

The microbiological quality assessment of the concentrates was made by identifying the quantitative and qualitative composition of microorganisms. Microbiological parameters were determined according to the following methods:

- the total quantity of mesophilic aerobic and facultative anaerobic microorganisms (QMAFAM) - by the method based on the ability of mesophilic aerobic and facultative anaerobic microorganisms to multiply on dense nutrient agar at $30 \ldots 31^{\circ} \mathrm{C}$ during 72 hours in accordance with the State Standard 8446:2015 [12];

- bacteria of the Escherichia coli group (BECG) - by the method based on the ability of BECG to ferment lactose in a Kessler medium with the formation of acid and gas in result at $37{ }^{\circ} \mathrm{C}$ during 24 hours in accordance with the State Standard ISO 4832:2015 [13];

- pathogenic microorganisms, including salmonella - according to the State Standard prEN ISO 6579-1:2014 by inoculating on selective mediums and establishing their specific enzymatic and serological properties [14];

- quantity of Staphylococcus aureus - using the Beard-Parker agar medium according to the State Standard ISO 6888-1:2003 [15]. 


\section{1. Experimental procedures}

When using a differential scanning calorimeter, the automatic temperature control system operates in the temperature range from $-196{ }^{\circ} \mathrm{C}$ to $+100{ }^{\circ} \mathrm{C}$ and allows either maintaining a constant temperature value of the calorimetric block, or scanning the temperature at a rate from $0,06{ }^{\circ} \mathrm{C} / \mathrm{min}$ to $2,5^{\circ} \mathrm{C} / \mathrm{min}$.

In this work, samples of MPC weighing $1 \mathrm{~g}$ were placed in a thin-walled glass of stainless steel, covered with a lid and cooled by immersion in liquid nitrogen. The average cooling rate was $200{ }^{\circ} \mathrm{C} / \mathrm{min}$. The thermograms were recorded at a heating rate of $0,5^{\circ} \mathrm{C} / \mathrm{min}$. The temperature measurement error was $\pm 0.2{ }^{\circ} \mathrm{C}$.

To measure the color-parametric characteristics, the intensity of the dark spectrum of the spectrophotometer was measured before the measuring of diffuse reflection spectra, then the spectrum of the reflection of the comparison sample was measured (in all experiments, the standard white sample No. 1 from a set of standard samples of HCOO-1 for SFO-2000 was used), after that the reflectance spectra of all studied samples were measured. For this, the cuvette was filled with a studied sample, placed in the prefix of diffuse reflection SFO-2000, and the diffuse reflection spectra were automatically measured in the range of $400 \ldots 800 \mathrm{~nm}$ with a step of $10 \mathrm{~nm}$.

After that, using the built-in SFScan software, the color characteristics of the studied samples were calculated based on the obtained reflection spectra. By means of mathematical processing of spectra of the studied samples, the color characteristics were determined in a tricolorimetric coordinate system.

Preparation of samples for microbiological research was made according to the State Standard IDF 122C: 2003 [16]. All studies were made in accordance with the current normative documentation of Ukraine and the world [12-16].

\section{Results}

The results of differential scanning calorimetry indicate that the process of glass transition is typical for all studied samples. This can be explained by the presence of bound water in their structure, which crystallizes not completely during the cooling process due to the high rate of temperature change. The structure of concentrates thus has the form of a mixture of ice crystals and solid amorphous inclusions, which makes possible to assume that it is stable in the solid state.

The obtained dependences of heat absorption on temperature (thermograms) of the studied samples gave the following results:

1) The temperature of MPC glass transition is placed in the range $-40 \ldots-80{ }^{\circ} \mathrm{C}$, which is wider than the range that is typical for control $\left(-50 \ldots-60^{\circ} \mathrm{C}\right)$. It should be noted that when temperature changes in the direction of $0{ }^{\circ} \mathrm{C}$, the bound water of MPC will pass into the state of supercooled viscous liquid. For the MPC studied, as well as for any products with amorphous consistency, such a transition will have negative consequences in terms of the harmlessness of the structure. Therefore, it would be advisable to choose a mode of freezing, which involves MPC storing at a temperature below $-80{ }^{\circ} \mathrm{C}$.

2) The melting point of the eutectic compositions of MPC is $-45^{\circ} \mathrm{C}$. Since, at the cooling stage, the eutectic compositions have converted to a solid crystalline state, their melting with the temperature increase will contribute to damage to the structure of the studied products. In this case, it is expedient to limit the temperature of storage of concentrates by a temperature corresponding to the melting of the eutectic compositions, namely $-45^{\circ} \mathrm{C}$.

3) Full melting of ice in the MPC passes at a temperature of $-7 \ldots-10^{\circ} \mathrm{C}$. This temperature corresponds to the destruction of ice macrocrystals, which is typical for the use of conventional freezing for the storage of concentrates. Given the significant deterioration of the organoleptic properties of MPC, the use of this freezing method is not expedient.

Analyzing the obtained data, one can conclude that in order to ensure the high quality of $\mathrm{MPC}$ in the process of storage, it is rational to use the method of rapid freezing up to $-20 \ldots-30{ }^{\circ} \mathrm{C}$, with subsequent storage at this temperature.

It should also be noted that the intensity of heat absorption leaks indicates an increase in the amount of bound liquid in the MPC in comparison with the control. This reduces crystallization 
and increases the glass transition during freezing. Consequently, the structure of concentrates undergoes a less degree of destruction, what indicates the priority of MPC in the context of maintaining a high level of quality during the storage in a frozen state.

The results of the analysis of color-parametric characteristics of MPC indicate the following:

1) The dominant spectral tone at the time of making for the MPCC sample is orange, but with the prolongation of storage time there is a significant shift in color towards yellow. In the case of MPCV, yellow is the dominant spectral color of the sample from the moment of its making.

2) Brightness parameters in the CIEXYZ system almost do not change over the entire storage time (37,2..40,5 \% for MPCV and 34,3...37,8 \% for MPCC), however, the dominant wavelength for both MPC gradually shifts to a yellow area of the visible spectrum $(578,9 \ldots 575,5 \mathrm{~nm}$ for MPCV and $585,1 . .575,8 \mathrm{~nm}$ for MPCC).

3) The parameter of tone purity, by contrast, undergoes significant changes during the samples storage period. So for MPCV it grows from 33,62 \% to 50,75\%, and for MPCC - from 12,58 \% to $34,73 \%$. The resulting growth indicates an increase in the contribution of the dominant tone to the overall color of the products, that is, the yellowing of MPC samples in the process of storage.

4) The contribution of the white tone to the total color of both products at the time of making amounts approximately $85 \%$, according to the parameters of the light (CIELab system). However, with an increase in storage time, the amount of white in the overall color range decreases significantly (to $57,93 \%$ for MPCV and 52,87 \% for MPCC). This indicates a gradual darkening of the product with prolongation of the storage time.

5) The parameters $a^{*}$ and $b^{*}$ in both cases have a value $>0$, which indicates red and yellow colors as dominant for both samples.

On the basis of the given data it can be concluded that the most rational is to store the samples in frozen state during 30 days from the time of making, because further storage will contribute to a rapid darkening and yellowing of both types of MPC.

The dynamics of changes in the microbiological indexes during storage is shown in Table $\mathbf{1 .}$

Table 1

The dynamics of changes in the microbiological indexes of MPC during storage

\begin{tabular}{|c|c|c|c|c|c|}
\hline \multirow[b]{2}{*}{ Indicator } & \multicolumn{4}{|c|}{ The content of microorganisms } & \multirow[b]{2}{*}{$\begin{array}{l}\text { Normative documents } \\
\qquad[11-14]\end{array}$} \\
\hline & $\begin{array}{l}\text { After mak- } \\
\quad \text { ing }\end{array}$ & $\begin{array}{c}\text { After } 30 \text { days } \\
\text { of storage } \\
\text { MPCV }\end{array}$ & $\begin{array}{l}\text { After } 60 \text { days } \\
\text { of storage }\end{array}$ & $\begin{array}{l}\text { After } 90 \text { days } \\
\text { of storage }\end{array}$ & \\
\hline $\begin{array}{l}\text { Bacteria of the Escherichia coli group } \\
\text { in } 0,01 \mathrm{~g} \text { of the product }\end{array}$ & \multicolumn{4}{|c|}{ not found } & not allowed \\
\hline $\begin{array}{l}\text { Pathogenic microorganisms, including } \\
\text { salmonella, in } 25 \mathrm{~g} \text { of the product }\end{array}$ & \multicolumn{4}{|c|}{ not found } & not allowed \\
\hline $\mathrm{S}$. aureus in $0,01 \mathrm{~g}$ of product & \multicolumn{4}{|c|}{ not found } & not allowed \\
\hline Microscopic mushrooms, NCU/g & 7 & 7 & 5 & 4 & 50 \\
\hline \multirow[t]{2}{*}{ Yeast, NCU/g } & 6 & 5 & 5 & 3 & 100 \\
\hline & & MPCC & & & \\
\hline $\begin{array}{l}\text { Bacteria of the Escherichia coli group } \\
\text { in } 0,01 \mathrm{~g} \text { of the product }\end{array}$ & \multicolumn{4}{|c|}{ not found } & not allowed \\
\hline $\begin{array}{l}\text { Pathogenic microorganisms, including } \\
\text { salmonella, in } 25 \mathrm{~g} \text { of the product }\end{array}$ & \multicolumn{4}{|c|}{ not found } & not allowed \\
\hline $\mathrm{S}$. aureus in $0,01 \mathrm{~g}$ of product & \multicolumn{4}{|c|}{ not found } & not allowed \\
\hline Microscopic mushrooms, NCU/g & 8 & 7 & 5 & 5 & 50 \\
\hline Yeast, NCU/g & 6 & 5 & 5 & 4 & 100 \\
\hline
\end{tabular}


The analysis of the data presented in the table 1 shows that the duration of MPC storage almost does not affect the development of the microflora. Thus, subject to storage at $-20 \ldots-25{ }^{\circ} \mathrm{C}$ for 90 days, the indicators of microbial damage in most cases do not change and stay within the normal limits. Changes are observed only in the decrease in the number of yeast and microscopic fungi, but they are negligible. Consequently, it can be assumed that subject to storage of the studied MPC at a temperature of $-20 \ldots-25^{\circ} \mathrm{C}$, the storage period is not important.

\section{Conclusions}

On the basis of the studies made, the phase transitions of the studied samples of MPC were analyzed and changes of heat absorption were considered. According to the results obtained, it was found that from all methods of freezing the most rational to maintain the high quality of studied $\mathrm{MBC}$ is using the rapid freezing to a temperature $-20 \ldots-30{ }^{\circ} \mathrm{C}$. The further storage of concentrates should also pass over this temperature.

The evaluation of the color-parametric characteristics of MPC was performed with the use of CIE XYZ and CIELab methods. The obtained data indicate that it is rational to store the studied products during 30 days from the time of making. The determined term is intended to prevent darkening and yellowing of concentrates and, accordingly, impairment of their quality.

It is determined that storage of concentrates in frozen condition does not have a significant effect on the development of microflora.

The obtained results were used to determine the storage regimes and shelf life of MBC experimental consignment at the Obukhiv Dairy Plant.

The researches presented in this article have advantages and disadvantages. Thus, the use of differential scanning calorimetry for analyzing phase transitions and changes in the structure of MPC allows to set the rate of temperature change for each experiment, which is especially attractive when it comes to studying the effect of different freezing methods on the structural characteristics of the product. At the same time, for more complete information on changes in the structure of the studied products, it is rational to use DSC additionally in combination with other methods of research - microscopy, methods of research of rheological characteristics, etc.

The proposed methods can be used to study microbiological purity, structural and color-parametric characteristics of various types of protein concentrates, co-precipitates and isolates, cottage cheeses and products based on them, as well as to analyze the dynamics of changes in these parameters in the process of the studied products storage.

\section{Acknowledgements}

We express our gratitude to the Institute of Problems of Cryobiology and Cryomedicine of the National Academy of Sciences of Ukraine.

\section{References}

[1] Tilly, J. (2017). Opportunities to Improve Nutrition for Older Adults and Reduce Risk of Poor Health Outcomes. Administration for Community Living or the U.S. Department of Health and Human Services. Available at: http://nutritionandaging.org/wp-content/uploads/2017/03/Malnutrition-Issue-Brief-final-3-2017.pdf

[2] Gnitsevich, V. A., Yudina, T. I. (2016). Analiz i perspektyvy vykorystannya bilkovo-vuhlevodnoyi molochnoyi syrovyny $\mathrm{v}$ Ukrayini [Analysis and prospects of using of protein-carbohydrate dairy raw materials in Ukraine]. Materials of the International Scientific-Practical Conference «Globalization Challenges for the Development of National Economies», 1190.

[3] Gnitsevich, V. A., Deinychenko, L. G. (2016). Innovaciyi u vyrobnycztvi molochno-bilkovyh koprecypitativ [Innovations in the production of milk-protein co-precipitates]. Abstracts of International Science-Practice Conference «Tourist, Hotel And Restaurant Business: Innovations and Trends», 362.

[4] Khramtsov, A. G. (2003). Ekspertiza vtorichnogo molochnogo syr'ya i poluchayemykh iz nego produktov [Expertise of secondary dairy raw materials and products derived from it]. St. Petersburg: GIORD, 120. 
[5] Gnitsevich, V. A., Yudina, T. I., Deinychenko, L. G. (2016). Tekhnolohiya ta biolohichna tsinnist' molochno-bilkovykh kopretsypitativ [Technology and biological value of milk-protein co-precipitates]. Tovaryi i ryinki, 2, 148-158.

[6] Affertsholt,, T., Fenger, M. (2014). The Global Market for Whey and Lactose Ingredients 2014-2017. 3A Business Consulting, 146.

[7] Khmarskaya, N. (2015). Novosti rynka ingrediyentov [News of ingredients market]. Produkty \& ingrediyenty, 9 (128), 11.

[8] Telis, V. R. N., Sobral, P. J. A. (2002). Glass transitions for freeze-dried and air-dried tomato. Food Research International, 35 (5), 435-443. doi: 10.1016/s0963-9969(01)00138-7

[9] Telis, V. R. N., Sobral, P. J. do A., Telis-Romero, J. (2006). Sorption Isotherm, Glass Transitions and State Diagram for Freeze-dried Plum Skin and Pulp. Food Science and Technology International, 12 (3), 181-187. doi: 10.1177/1082013206065953

[10] Bai, Y., Rahman, M. S., Perera, C. O., Smith, B., Melton, L. D. (2001). State diagram of apple slices: glass transition and freezing curves. Food Research International, 34 (2-3), 89-95. doi: 10.1016/s09639969(00)00128-9

[11] Novoselskaya, O. (2014). Konspekt lektsii po distsipline «Teoriya tsveta i tsvetovosproizvedeniya» dlya studentov spetsial'nosti 1-47 0201 Tekhnologiya poligraficheskikh proizvodstv [Lecture notes on discipline «Theory of color and color reproductions» for students of specialty 1-470201 Technology of polygraphic productions]. Available at: https://www.belstu.by/Portals/0/userfiles/87/KONSPEKT-LEKCIJ.pdf

[12] State Standard 8446:2015. (2015). Food products. Methods of determining the number of mesophilic aerobic and facultative anaerobic microorganisms. Kyiv: SS NUBNM of Ukraine «RPI of standardization and technologies of eco-safety and organic products», 16. (In Ukrainian).

[13] State Standard ISO 4832:2015. (2015). Microbiology of food and animal feeding stuffs - Horizontal method for the enumeration of coliforms - Colony-count technique, 6. (In Ukrainian).

[14] State Standard EN ISO 6579-1:2014. (2014). Microbiology of the food chain - Horizontal method for the detection, enumeration and serotyping of Salmonella - Part 1: Detection of Salmonella spp, 50. (In Ukrainian).

[15] State Standard ISO 6888-1:2003. (2003). Microbiology of food and animal feeding stuffs - Horizontal method for the enumeration of coagulase-positive staphylococci (Staphylococcus aureus and other species) - Part 1: Technique using Baird-Parker agar medium, 14. (In Ukrainian).

[16] State Standard IDF 122C:2003. (2003). Milk and dairy products. Preparation of samples and dilutions for microbiological research, 12. (In Ukrainian). 